\title{
Actinobacteria from Termite Mounds Show Antiviral Activity against Bovine Viral Diarrhea Virus, a Surrogate Model for Hepatitis C Virus
}

\author{
Marina Aiello Padilla, ${ }^{1}$ Rodney Alexandre Ferreira Rodrigues, ${ }^{2}$ \\ Juliana Cristina Santiago Bastos, ${ }^{1}$ Matheus Cavalheiro Martini, ${ }^{1}$ \\ Ana Caroline de Souza Barnabé, ${ }^{1}$ Luciana Konecny Kohn, ${ }^{1}$ \\ Ana Paula Trovatti Uetanabaro, ${ }^{3}$ Getúlio Freitas Bomfim, ${ }^{4}$ \\ Rafael Sanches Afonso, ${ }^{2}$ Fabiana Fantinatti-Garboggini, ${ }^{2}$ and Clarice Weis Arns ${ }^{1}$ \\ ${ }^{1}$ Laboratory of Virology, Department of Genetics and Evolution and Bioagents, Institute of Biology, \\ University of Campinas (UNICAMP), P.O. Box 6109, 13083-970 Campinas, SP, Brazil \\ ${ }^{2}$ Multidisciplinary Center for Chemical Biological and Agricultural Research, University of Campinas (UNICAMP), \\ Avenida Alexandre Cazelatto 999, Betel, 13148-218 Paulínia, SP, Brazil \\ ${ }^{3}$ University of Santa Cruz (UESC), Campus Soane Nazaré de Andrade, Rodovia Jorge Amado, km 16, Salobrinho, \\ 45662-900 Ilhéus, BA, Brazil \\ ${ }^{4}$ University of Feira de Santana (UEFS), Avenida Transnordestina, s/n, Novo Horizonte, 44036-900 Feira de Santana, BA, Brazil
}

Correspondence should be addressed to Clarice Weis Arns; clarns@gmail.com

Received 28 May 2015; Accepted 28 September 2015

Academic Editor: Nunziatina De Tommasi

Copyright (C) 2015 Marina Aiello Padilla et al. This is an open access article distributed under the Creative Commons Attribution License, which permits unrestricted use, distribution, and reproduction in any medium, provided the original work is properly cited.

\begin{abstract}
Extracts from termite-associated bacteria were evaluated for in vitro antiviral activity against bovine viral diarrhea virus (BVDV). Two bacterial strains were identified as active, with percentages of inhibition (IP) equal to $98 \%$. Both strains were subjected to functional analysis via the addition of virus and extract at different time points in cell culture; the results showed that they were effective as posttreatments. Moreover, we performed MTT colorimetric assays to identify the $\mathrm{CC}_{50}, \mathrm{IC}_{50}$, and SI values of these strains, and strain CDPA27 was considered the most promising. In parallel, the isolates were identified as Streptomyces through $16 \mathrm{~S}$ rRNA gene sequencing analysis. Specifically, CDPA27 was identified as S. chartreusis. The CDPA27 extract was fractionated on a C18-E SPE cartridge, and the fractions were reevaluated. A $100 \%$ methanol fraction was identified to contain the compound(s) responsible for antiviral activity, which had an SI of 262.41. GC-MS analysis showed that this activity was likely associated with the compound(s) that had a peak retention time of $5 \mathrm{~min}$. Taken together, the results of the present study provide new information for antiviral research using natural sources, demonstrate the antiviral potential of Streptomyces chartreusis compounds isolated from termite mounds against BVDV, and lay the foundation for further studies on the treatment of HCV infection.
\end{abstract}

\section{Introduction}

Infections with bovine viral diarrhea virus (BVDV) lead to significant economic losses for cattle producers worldwide. This virus is associated with transient fever and diarrhea as well as disorders that affect milk production [1]. BVDV is a member of the Flaviviridae family and Pestivirus genus [2]. While there are differences among the members of this genus,
BVDV shares similarities in replication cycle, biology, and genetic organization with hepatitis $\mathrm{C}(\mathrm{HCV})$, a member of the same family as BVDV but from the Hepacivirus genus [3].

Based on these similarities, BVDV is widely used as a surrogate model for in vitro antiviral studies against $\mathrm{HCV}$, as HCV does not efficiently replicate in cell culture [4].

There are no available vaccines for the prevention of $\mathrm{HCV}$ infection, and current therapy involves a combination of 
interferon-R (PEG-INF) and ribavirin (1- $\beta$-D-ribofuranosyl$1,2,4$ triazole-3-carboxamide), a nucleoside analog $[5,6]$. In addition to its costliness, this treatment is only effective for HCV genotype 1-infected patients and produces numerous side effects, including psychiatric disorders, hemolytic anemia, and changes in blood cell counts, leading to discontinuation $[5,7]$. Protease inhibitors (PI), including boceprevir and telaprevir, have revolutionized the treatment of HCV genotype 1 infections; however, combination treatments using PIs have been associated with adverse events, which also lead to the early termination of therapy [8].

Thus, the development of a low-cost therapy with few collateral side effects is a priority.

Natural products comprise substances with diverse chemical structures, providing a substantial pool of potential new drugs $[9,10]$.

In traditional medicine, termites and termite mounds have been used to treat different diseases worldwide. The termite is commonly used in northern Brazil and in indigenous communities in different parts of the world, such as in the Pareci and Kadiwéu communities, particularly for the treatment of asthma and dermatological problems [11-13]. Additionally, the use of tea-crushed insects or inhalation of incinerated termite soil has previously been reported in cases of bronchitis, wounds, colds, flu, rheumatism, and other conditions [12]. Recently, the termite has also been described as a source of natural products with antibiotic and antifungal activities [14].

Because of the significant difficulties in treating and preventing $\mathrm{HCV}$ and the therapeutic potential of natural compounds with antiviral activities, we analyzed the effects of bacteria collected from different termite mounds against BVDV.

\section{Materials and Methods}

\subsection{Bacteria}

2.1.1. Isolation and Maintenance of Microorganisms. Samples of termite mounds were collected between October 2008 and February 2009 from different municipalities in Bahia, Brazil, including Morro do Chapéu ( $\left.11^{\circ} 33^{\prime} 08^{\prime \prime} \mathrm{S}, 41^{\circ} 09^{\prime} 27^{\prime \prime} \mathrm{W}\right)$, Lafaiete Coutinho $\left(13^{\circ} 38^{\prime} 11^{\prime \prime} \mathrm{S}, 40^{\circ} 12^{\prime} 43^{\prime \prime} \mathrm{W}\right)$, and Feira de Santana $\left(12^{\circ} 16^{\prime} 23^{\prime \prime} \mathrm{S}, 38^{\circ} 57^{\prime} 19^{\prime \prime} \mathrm{W}\right)$. The samples were placed in sterilized polyethylene bags and immediately transported to the Laboratório de Pesquisa em Microbiologia (LAPEM) at Universidade de Feira de Santana, Bahia, Brazil. A 10 g sample of termite mound was suspended in $90 \mathrm{~mL}$ of sterile water and manually homogenized for $2 \mathrm{~min}$. Aliquots of $100 \mathrm{~mL}\left(10^{-1}\right.$ at $10^{-5}$ ) were inoculated onto Petri dishes containing three different media: ISP2A (10.0 g soluble starch, $4.0 \mathrm{~g}$ yeast extract, $10.0 \mathrm{~g}$ malt extract, $4.0 \mathrm{~g}$ dextrose, and $20.0 \mathrm{~g}$ agar in $1000 \mathrm{~mL}$ distilled water; $\mathrm{pH}$ 7.0-7.2); CCA (10 g soluble starch, $0.3 \mathrm{~g}$ $\mathrm{KNO}_{3}, 2.0 \mathrm{~g} \mathrm{NaCl}, 2.0 \mathrm{~g} \mathrm{~K}_{2} \mathrm{PO}_{4} \cdot 3 \mathrm{H}_{2} \mathrm{O}, 2.0 \mathrm{~g} \mathrm{MgSO}$, $0.02 \mathrm{~g}$ $\mathrm{CaCo}_{3}, 0.01 \mathrm{~g} \mathrm{FeSO}_{4}$, and $20.0 \mathrm{~g}$ agar in $1000 \mathrm{~mL}$ distilled water; pH 7.0-7.2), and ISP3 (HIMEDIA). The culture media were supplemented with cycloheximide $\left(50 \mathrm{mg} \mathrm{mL}^{-1}\right)$ to control fungal growth. All plates were incubated at $30^{\circ} \mathrm{C}$, and the appearance of colonies for bacterial isolation was assessed daily. Pure cultures were obtained after serial transfer into the same culture conditions as above for isolation. The isolates were maintained at $-80^{\circ} \mathrm{C}$ in $20 \%$ glycerol until further use.

2.1.2. Identification of Bacteria through $16 S$ rRNA Gene Sequencing Analysis. After allowing the bacteria to grow on agar plates, genomic DNA was extracted from the pure cultures according to a protocol published by Van Soolingen et al. [15]. The $16 \mathrm{~S}$ ribosomal DNA gene fragments were PCR-amplified using the primers p10f $\left(5^{\prime}\right.$ GAG TTT GAT CCT GGC TCA G $3^{\prime}$ ) and 1525R ( $5^{\prime}$ AAG GAG GTG CC 3 WTC CAR $3^{\prime}$ ), which were homologous to conserved regions of the bacterial 16S ribosomal RNA (rRNA) gene [16]. Fifty-microliter reaction mixtures containing 50-100 ng genomic DNA, 2 U Taq DNA polymerase (Invitrogen), 1x Taq buffer, $1.5 \mathrm{mM} \mathrm{MgCl}_{2}, 0.2 \mathrm{mM}$ dNTP mix (GE Healthcare), and $0.4 \mu \mathrm{M}$ of each primer were used. The amplification program included 1 cycle at $95^{\circ} \mathrm{C}$ for $2 \mathrm{~min}, 30$ cycles at $94^{\circ} \mathrm{C}$ for $1 \mathrm{~min}, 55^{\circ} \mathrm{C}$ for $1 \mathrm{~min}, 72^{\circ} \mathrm{C}$ for $3 \mathrm{~min}$, and a final extension at $72^{\circ} \mathrm{C}$ for $3 \mathrm{~min}$ using an Eppendorf thermal cycler. PCR amplification of the 16S rRNA gene fragments was confirmed on a $1 \%$ agarose gel stained with SYBR Safe (Invitrogen). The 16S rRNA gene fragments were further purified using mini columns (GFX PCR DNA and Gel Band Purification Kit, GE Healthcare) and sequenced using an automated sequencer (ABI3500xL). The sequencing reactions were performed using a BigDye Terminator v3.1 Sequencing Kit (Life Technologies). The primers used in the sequencing reactions were $10 \mathrm{f}\left(5^{\prime}\right.$ GAG TTT GAT CCT GGC TCA G $3^{\prime}$ ), p765f ( $5^{\prime}$ AGA TAC ATT CCT GGT AG $\left.3^{\prime}\right)$, p782r ( $5^{\prime}$ ACC AGG GTA TCT AAT CCT GT $\left.3^{\prime}\right)$, 1100R ( $5^{\prime}$ GGC CTC AGG GTT GTT G 3'), and 1525R (5' AAG GAG GTG CC 3 WTC CAR $3^{\prime}$ ). The obtained sequences were processed using the Phred/Phrap/Linux version of the CONSED program for the assembly of contigs $[17,18]$. The final obtained sequence was approximately $1100 \mathrm{bp}$ and was compared against sequences in GenBank (http://www.ncbi.nlm.nih.gov/BLAST/) and Ribosomal Data Project II 9.0 (http://rdp.cme.msu.edu/index.jsp). Sequences retrieved from the databases were aligned using the CLUSTAL X program [19], and phylogenetic analyses were conducted using the MEGA program, version 5 [20]. An evolutionary distance matrix was calculated using a previously described model [21], and a phylogenetic tree was constructed based on evolutionary distances using the neighbor-joining method [22], with values calculated from 1000 bootstrap resamples [23].

\subsection{Extracts}

2.2.1. Crude Extracts. A total of 90 bacterial extracts were obtained using liquid-liquid extraction [3]. Briefly, a preinoculum of the isolates was cultured in $7 \mathrm{~mL}$ of isolation medium (Nutrient Broth, NB) and incubated at $30^{\circ} \mathrm{C}$ at $120 \mathrm{rpm}$. After $48 \mathrm{~h}$, the total volume was transferred to an Erlenmeyer flask containing $50 \mathrm{~mL}$ of the same medium and maintained at the same temperature and rotation for $48 \mathrm{~h}$. Subsequently, $50 \mathrm{~mL}$ of the bacterial suspension was transferred to a glass jar containing $500 \mathrm{~mL}$ of the same 
medium and maintained under the same conditions as above for four weeks. Then, $500 \mathrm{~mL}$ of P.A. grade ethyl acetate was added, and the mixture was triturated in a blender at high-speed rotation. After $24 \mathrm{~h}$, the mixture was filtered using a Buchner funnel containing a PTFE frit-layer of Celite (diatomaceous earth), and the organic phase was recovered in an Erlenmeyer flask using a separator funnel. Cell debris and culture medium were retained in the aqueous phase, and potentially biologically active metabolites were recovered in the organic phase. The organic phase was transferred to a round-bottom flask.

The organic solvent was removed using a Buchi Rotavapor R-215 with vacuum at $37^{\circ} \mathrm{C}$ until the solvent was completely dry. Subsequently, the extracts were suspended in ethyl acetate and water and transferred to new glass tubes using Pasteur pipettes. These tubes were placed in a Savant vacuum centrifuge (model 210A SpeedVac Plus SC) for evaporation, and the samples were freeze-dried. After complete drying, the extracts were dissolved in $10 \%$ dimethylsulfoxide (DMSO) and maintained at $-4^{\circ} \mathrm{C}$ until further use in antiviral activity assays.

2.2.2. Fractionation. The extract presenting the best results, that is, the highest inhibition percentage (IP) and highest selectivity index (SI), was selected for fractionation to identify the potential active compound(s) responsible for its antiviral activity.

The extracts were fractionated using Phenomenex Strata Reversed Phase C18-E SPE cartridges containing $500 \mathrm{mg}$ of adsorbent (sorbent lot number S201-141). Each cartridge was preconditioned with $100 \%$ methanol $(3 \mathrm{~mL})$ and equilibrated with $100 \%$ water $(3 \mathrm{~mL})$. Subsequently, each sample was loaded onto the top of the cartridge using a Pasteur pipette at $30 \mathrm{mg} / \mathrm{mL}$ sorbent mass, followed by elution with $3 \mathrm{~mL}$ of a water/methanol mixture in a gradient starting from the first fraction. The following fractions were sequentially collected: (1) water/methanol (95/05), (2) water/methanol (90/10), (3) water/methanol (80/20), (4) water/methanol (70:30), and (5) water/methanol $(50: 50)$. At the end of the procedure, the cartridge was rinsed with $100 \%$ methanol to remove unbound material, which was designated fraction 6 . The fractions were stored at $8^{\circ} \mathrm{C}$ until antiviral activity analysis using GC-MS coupling.

\subsection{Antiviral Activity Assay}

2.3.1. Virus and Cell Lines. The Madin-Darby bovine kidney (MDBK) cell line was used for inoculation with the BVDV strain Cepa Singer. The virus was propagated in monolayer culture using minimal essential medium (MEM) containing Earle's salts. The MDBK cells were supplemented with $10 \%$ equine serum (ES). Medium without serum was used when the virus was incubated with the MDBK cells.

2.3.2. MTT Assay. The MTT assay is a sensitive in vitro assay for the measurement of cell proliferation or cell viability reduction. To perform the assay, the MDBK cells were cultured in 96-well tissue culture plates. The tetrazolium compound MTT (3-[4,5-dimethylthiazol-2-yl]2,5-diphenyltetrazolium bromide) was then added to the wells, and the plates were further incubated. MTT is reduced to insoluble purple formazan crystals in metabolically active cells. An aliquot of $150 \mu \mathrm{L}$ DMSO was subsequently added to each well to solubilize the crystals, and the absorbance was read at $540 \mathrm{~nm}$ using a spectrophotometer [24, 25]. The data were analyzed after plotting cell number versus absorbance to quantitate changes in cell proliferation. The rate of tetrazolium reduction is proportional to the rate of cell proliferation and indirectly indicates reductions in cell viability in response to virus infection.

2.3.3. Titration of the Virus. Cells were seeded onto 96-well culture plates at a density of $10^{5}$ cells $/ \mathrm{mL}$ and subsequently incubated at $37^{\circ} \mathrm{C}$ for $24 \mathrm{~h}$ in a humidified atmosphere containing $\mathrm{CO}_{2}$. Tenfold serial dilutions of the virus stocks were prepared in culture medium, and the cells were infected with the diluted virus. After additional incubation (1-2 days), the cytopathic effect was recorded. The $50 \%$ tissue-culture infective dose $\left(\mathrm{TCID}_{50}\right)$ per $\mathrm{mL}$ was calculated as previously described [26].

2.3.4. Antiviral Activity. Antiviral activity was determined based on inhibition of the cytopathic effect. All experiments were performed in quadruplicate. Briefly, to evaluate inhibition, cells were seeded onto 96-well culture plates. After incubation for $24 \mathrm{~h}$, the medium was replaced with $100 \mu \mathrm{L}$ of MEM(E) containing $50 \mu \mathrm{g} / \mathrm{mL}$ bacterial extract, and $50 \mu \mathrm{L}$ of $100 \mathrm{TCID}_{50} / 50 \mu \mathrm{L}$ of virus was added and incubated for $72 \mathrm{~h}$. The controls comprised untreated infected cells (virus at 100 $\mathrm{TCID}_{50} / 50 \mu \mathrm{L}$ ), treated noninfected cells (extract control), and untreated noninfected cells. The cytopathic effect was observed, and the extracts possessing antiviral activity were identified. Antiviral activity was determined using an MTT assay to quantify the protection conferred by a cell extract against the virus. The protection percentage was calculated using the following formula [27]: (absorbance of treated cells - absorbance of the control virus)/(absorbance of the cellular control - absorbance of the control virus) $\times 100$. The antiviral activity was initially evaluated with a single dose of $50 \mu \mathrm{g} / \mathrm{mL}$ against $100 \mathrm{TCID}_{50} / \mathrm{mL}$ of virus. Extracts with activities higher than $90 \%$ were considered promising. However, only extracts with IPs higher than $98 \%$ were considered active and selected for further examination.

To confirm antiviral activity, a concentration-response curve using different concentrations of extract in the presence of $100 \mathrm{TCID}_{50} / \mathrm{mL}$ of virus was constructed using the MTT assay to determine the $50 \%$ inhibitory concentration $\left(\mathrm{IC}_{50}\right)$. The $\mathrm{IC}_{50}$ was calculated from the concentration-response curve using linear regression analysis. The results were obtained from triplicate assays using at least five extract concentrations. The $50 \%$ cytotoxicity concentration $\left(\mathrm{CC}_{50}\right)$ was calculated as $[(A-B) / A] \times 100$, where $A$ and $B$ represent the $\mathrm{OD}_{540}$ values of untreated and treated cells, respectively. The percentage protection was calculated as $[(A-B) \times$ $100 /(C-B)]$, where $A, B$, and $C$ indicate the absorbance values of the extract, virus, and control cells, respectively. 


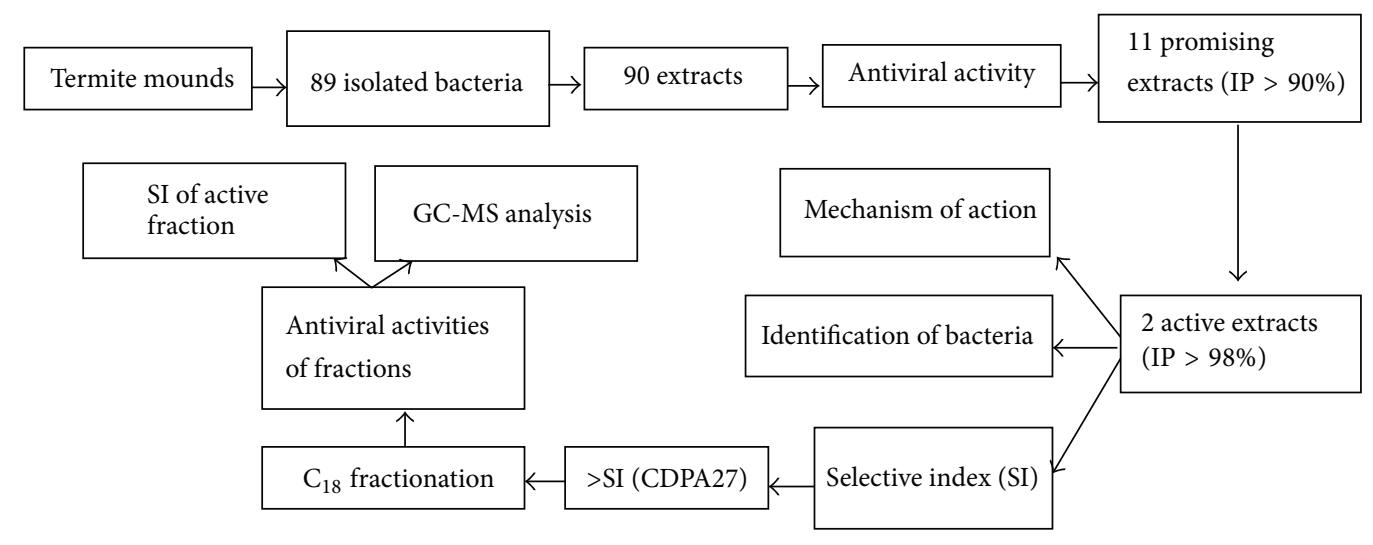

FIGURE 1: Experimental design employed in this study.

Each $\mathrm{IC}_{50}$ value was defined as the effective concentration necessary to reduce the absorbance of infected cells by $50 \%$ compared with the cell and virus controls. The $\mathrm{CC}_{50}$ and $\mathrm{IC}_{50}$ values represented the averages of three assays using five concentrations within the inhibitory ranges of the compounds. The therapeutic index (i.e., SI) was defined as $\mathrm{CC}_{50} / \mathrm{IC}_{50}$.

2.3.5. Viral Infection Cycle Staging. Cells and viruses were incubated with active extracts at different stages during the viral infection cycle to determine the antiviral mechanism. The cells were pretreated with bacterial samples prior to viral infection (pretreatment); viruses were incubated with the bacterial samples prior to infecting the cells (virucidal action); or the cells were infected and incubated together with the virus before the addition of the bacterial samples (posttreatment). The samples were used at the maximum noncytotoxic concentration. The antiviral activity was expressed as the titer $\left(\mathrm{TCID}_{50} / \mu \mathrm{L}\right)$ and IP, as previously described by Koseki et al. [28]. The IP was calculated using the formula $(\mathrm{IP})=(1-T / C) \times 100$, where $T$ is the antilog of the extracttreated viral titers and $C$ is the antilog of the control (without extract) viral titers. An IP greater than or equal to $97 \%$ was considered positive.

2.4. GC-MS Analysis. The crude extracts and active fractions were analyzed using GC-MS. The analyses were performed on an Agilent 6890N gas chromatograph (Palo Alto, CA, USA) interfaced with an Agilent 5975 Mass Selective Detector and an HP 7683B automatic injector, fitted with a fused methyl silicon HP-5MS column $(30 \mathrm{~m} \times 0.25 \mathrm{~mm}$ i.d., $0.25 \mu \mathrm{m}$ film thickness) containing 5\% phenyl and 95\% methylsiloxane. Helium was used as a carrier gas at a flow rate of $1.0 \mathrm{~mL} / \mathrm{min}$. The oven temperature was maintained at $150^{\circ} \mathrm{C}$ for $2 \mathrm{~min}$ and subsequently increased to $240^{\circ} \mathrm{C}$ at a rate of $5^{\circ} \mathrm{C} / \mathrm{min}$, followed by an increase to $300^{\circ} \mathrm{C}$ at a rate of $10^{\circ} \mathrm{C} / \mathrm{min}$. It was then maintained constant for at least $34 \mathrm{~min}$. The injector temperature was maintained at $280^{\circ} \mathrm{C}$, and the split ratio was adjusted to $1: 50$. Mass spectral (MS) data were obtained under the following conditions: ionization potential $70 \mathrm{eV}$, 50-480 amu scan range, 2 sec scan time, detector temperature $300^{\circ} \mathrm{C}$, and solvent delay $3 \mathrm{~min}$. The samples were solubilized in ethyl acetate at a concentration of $20 \mathrm{mg} / \mathrm{mL}$ and injected into a gas chromatograph column. The constituents of the extracts were identified by comparing the mass spectral data and retention times with corresponding data obtained from the literature and the NIST 2005 computerized MS databank, using $90 \%$ as the minimum identification criterion.

2.5. Statistical Analysis. The results are expressed as the means \pm SEM. Significantly different effects of the tested extracts on the inhibition of virus replication were compared with the control group using Student's $t$-test, with significance considered at $p \leq 0.05$.

\section{Results}

A total of 90 extracts from different bacterial species previously collected from termites in three regions of Bahia in northeastern Brazil (Lafaiete Coutinho, Feira de Santana, and Morro do Chapéu) were examined. The culture medium used for bacterial growth (NB medium, Oxoid) was used as a control to ensure that there was no interference with the tested compounds produced from the bacteria.

Among the extracts analyzed, 11 samples showed IP values against BVDV that were greater than or equal to $90 \%$. A flowchart of the experiments is shown in Figure 1.

The extracts listed in Figure 2 showed promising results. The active extracts with IP values greater than $98 \%$ included CDPA27 and MC51. The stage of the viral replication cycle during which the extracts exerted their actions was identified, and the SI values (i.e., $\mathrm{CC}_{50} / \mathrm{IC}_{50}$ ) of the compounds, which indicate their potential to inhibit viral replication without inducing cell damage, were calculated. Thus, a direct relationship could be established between SI value and the potential of an extract as an antiviral compound. To identify the stage of the viral replication cycle during which an active compound operated, three different treatments were administered: (1) the cells were infected with virus for $1 \mathrm{~h}$, followed by the addition of extract to evaluate the viral replication phase (posttreatment); (2) the virus was pretreated with extract prior to infecting the cells (virus inactivation); and (3) extract 
TABLE 1: Potential mechanism, selectivity index (SI), 50\% cytotoxicity concentration $\left(\mathrm{CC}_{50}\right)$, and concentration inhibiting $50 \%$ viral replication $\left(\mathrm{IC}_{50}\right)$ of the active extracts.

\begin{tabular}{cccccc}
\hline Virus & Extract & CC $_{50}$ & IC $_{50}$ & SI & Mechanism of action \\
\hline \multirow{2}{*}{ BVDV } & CDPA27 & 409.3 & 139.8 & 3.50 & Posttreatment \\
& MC51 & 32.31 & 16.99 & 1.90 & Posttreatment \\
\hline
\end{tabular}

BVDV: bovine viral diarrhea virus; $\mathrm{CC}_{50}$ : concentration inhibiting $50 \%$ cell growth; $\mathrm{IC}_{50}$ : concentration inhibiting $50 \%$ viral replication.

TABLE 2

\begin{tabular}{lccc}
\hline Active fraction & $\mathrm{CC}_{50}$ & $\mathrm{IC}_{50}$ & SI \\
\hline Fraction $6(100 \% \mathrm{MeOH})$ & 227.8 & 0.8681 & 262.4121 \\
\hline
\end{tabular}

$\mathrm{CC}_{50}$ : concentration inhibiting $50 \%$ cell growth; $\mathrm{IC}_{50}$ : concentration inhibiting $50 \%$ viral replication; SI: selectivity index.

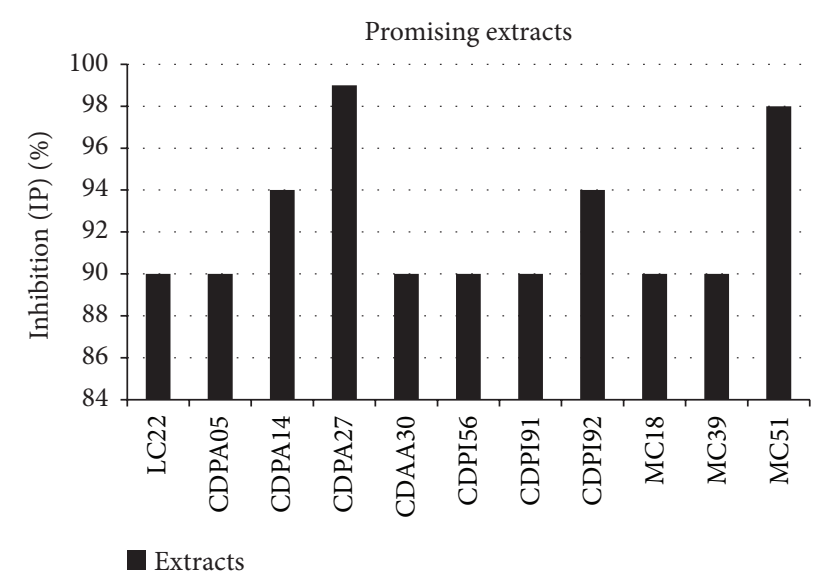

FIgURE 2: Percentages of inhibition (IP) of the promising extracts.

was added to the cells prior to viral infection to evaluate viral adsorption effects (pretreatment). The SI results and identified mechanisms of action are detailed in Table 1.

In addition, we conducted a phylogenetic analysis of the active bacterial compounds based on the ribosomal operon to identify these microorganisms. This technique is useful for the identification of many bacterial species. In the present study, the strain with the highest degree of activity against BVDV, strain CPDA27, was identified as Streptomyces chartreusis. Strain MC51 was also identified as a member of the Streptomyces genus; however, it was not possible to identify the species of this strain. The phylogenetic tree that was constructed using the above data is presented in Figure 3.

According to the above results, the $S$. chartreusis extract had the best IP and SI values. Thus, this strain was selected for further analysis via fractionation using a C18-E cartridge, and the fractions were reevaluated. The results are shown in Figure 4 and Table 2. Analyzing the IP values of the fractions revealed that fraction $6(100 \%$ methanol) contained the compounds responsible for the observed antiviral activity (Figure 4). The SI of the active fraction, highlighted in Table 2, was 262.41, supporting the use of this sample in future assays.
To identify the compounds responsible for the antiviral activity described in the present study, the crude bacterial extract, the active fraction, and a control sample of the culture medium without bacteria were analyzed using GC-MS. It was possible to identify the compounds present in both the crude extract and the active fraction and those that were not present in the control sample, suggesting that these compounds were solely derived from S. chartreusis fermentation (Figure 5).

Compared with the control, peaks were observed at certain retention times that corresponded to the compounds derived exclusively from bacterial fermentation and that were potentially responsible for antiviral activity. The chromatographic analysis of the CDPA27 extract revealed that the compounds produced by the bacteria appeared at the beginning of the chromatogram. These same compounds were also identified in active fraction 6 (100\% methanol).

Thus, these results suggest that the antiviral activity against BVDV described in the present study is associated with the compounds that produced peaks with 5 min retention times.

Although the compounds identified in the present study were thoroughly analyzed, it was not possible to detect similarities between the compounds represented by each peak on the mass fragmentogram and the compounds present in the utilized databases.

\section{Discussion}

Approximately $3 \%$ of the world's population (170 million people) is afflicted with chronic HCV infections, which pose a risk for the development of cirrhosis, hepatocellular carcinoma, and liver failure [29-31].

The search for new therapeutic agents to control virus infection is one of the highest priorities in virological research [32], and an increasing number of recent studies have focused on utilizing natural sources to solve medical challenges [33].

Despite the popular use of termites and termite mounds in populations from different regions of the world [12], the antifungal [34] and antibiotic properties [35] of these treatments have only recently been examined. In the present study, we examined the potential antiviral activities of termiteassociated bacteria.

A major component of the microbiota of several species of termites is Actinobacteria, which are present in the intestines and on the body surfaces of these insects $[36,37]$. Actinobacteria, also known as actinomycetes, are Gram-positive bacteria that produce a variety of secondary metabolites considered to be promising candidates for active natural compounds [35].

In the extracts tested in the current study, the strains CDPA27 and MC51 were the most promising, and phylogenetic analysis identified both strains as Streptomyces. This genus has also consistently been described to produce secondary metabolites, such as those obtained from Streptomyces sp. K15, with significant antimicrobial activities against Botrytis cinerea [38]. Additionally, other Streptomyces species, such as $S$. mutabilis, which was isolated from soil samples in Saudi Arabia, exhibit promising antituberculous activity [39], and Raveh et al. [40] reported the antiviral activity of 


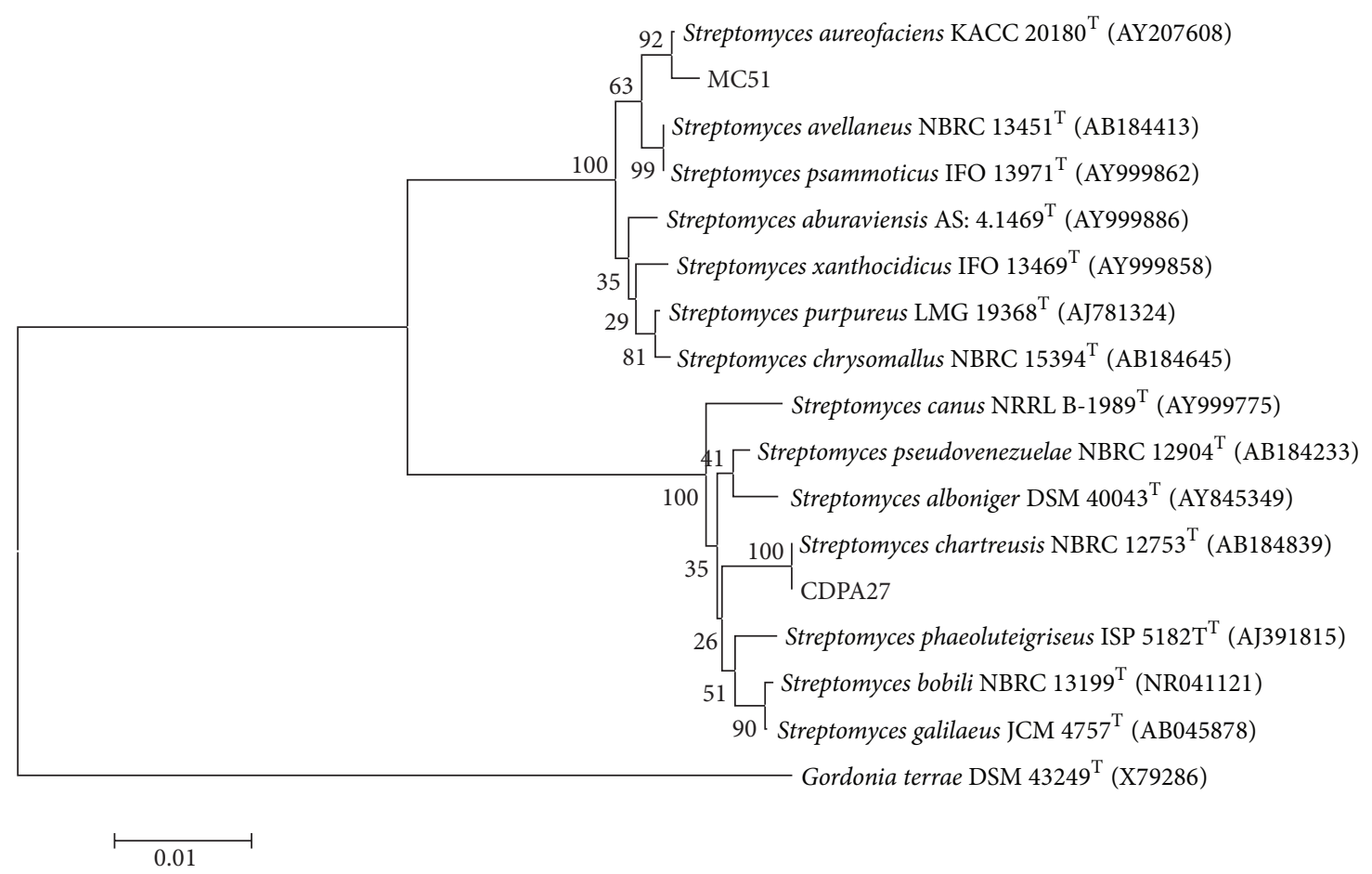

Figure 3: Phylogenetic tree based on the analyses of $16 \mathrm{~S}$ ribosomal RNA gene sequences of Actinobacteria (Kimura 2-parameter model, neighbor-joining algorithm with 1000 bootstrap resamples). The sequence of the $16 \mathrm{~S}$ ribosomal RNA gene from Gordonia terraeT (X79286) was used as an outgroup.

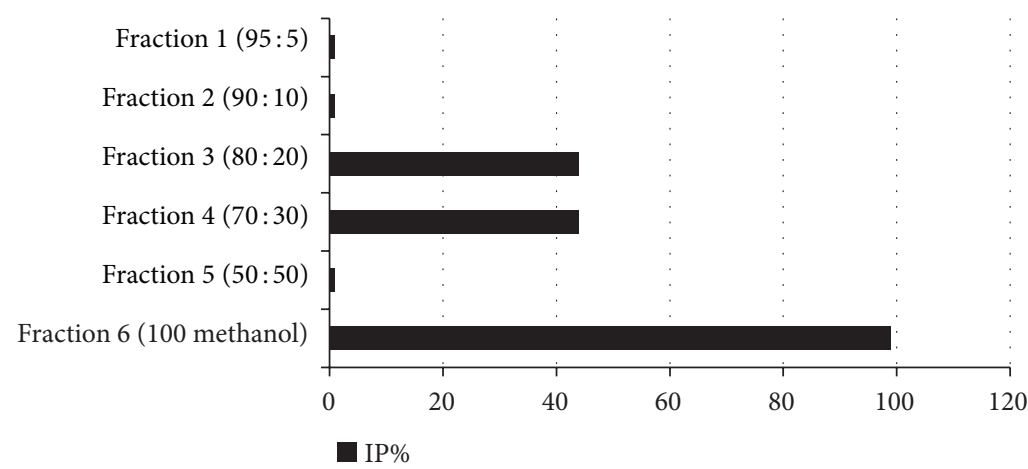

FIGURe 4: Percentage of inhibition (IP), selectivity index (SI), concentration inhibiting $50 \%$ cell growth $\left(\mathrm{CC}_{50}\right)$, and concentration inhibiting $50 \%$ viral replication $\left(\mathrm{IC}_{50}\right)$ of the active fraction (see Table 2 ).

a compound isolated from marine sediments obtained from S. kaviengensis against western equine encephalitis virus that inhibits the mitochondrial electron transport chain.

The most promising extract in the current study was derived from the fermentation of $S$. chartreusis. Leach et al. [41] first described this species as being responsible for the production of chartreusin, a compound with antibiotic properties against many Gram-positive species, such as Bacillus subtilis and Brucella bronchiseptica, and Gram-negative species, such as Salmonella typhosa, Escherichia coli, and Proteus vulgaris; chartreusin has also shown activity against mycobacteria. In 1958, Miyakawa et al. [42] evaluated the antiviral activities of several antibiotics against influenza A (strain $\mathrm{RP}_{8}$ ) and further confirmed the significant activity of this compound. Moreover, chartreusin has also been described to possess antitumor activity against murine L1210 and P388 leukemias and B16 melanoma [43]. Furthermore, Aoyama et al. [44] described a minor component of crude chartreusin (3-demethylchartreusin) as a new antitumor antibiotic.

In the present study, the results of antiviral activity assays revealed that CDPA27 affects viral replication; that is, it acts as a posttreatment. This result is consistent with the antitumoral mechanism of chartreusin, which binds to DNA and inhibits the activity of topoisomerase II, interfering with subsequent stages of replication [45]. However, GC-MS analysis did not detect overlaps between database results and the compounds of interest that were present in the fractions and crude extract 

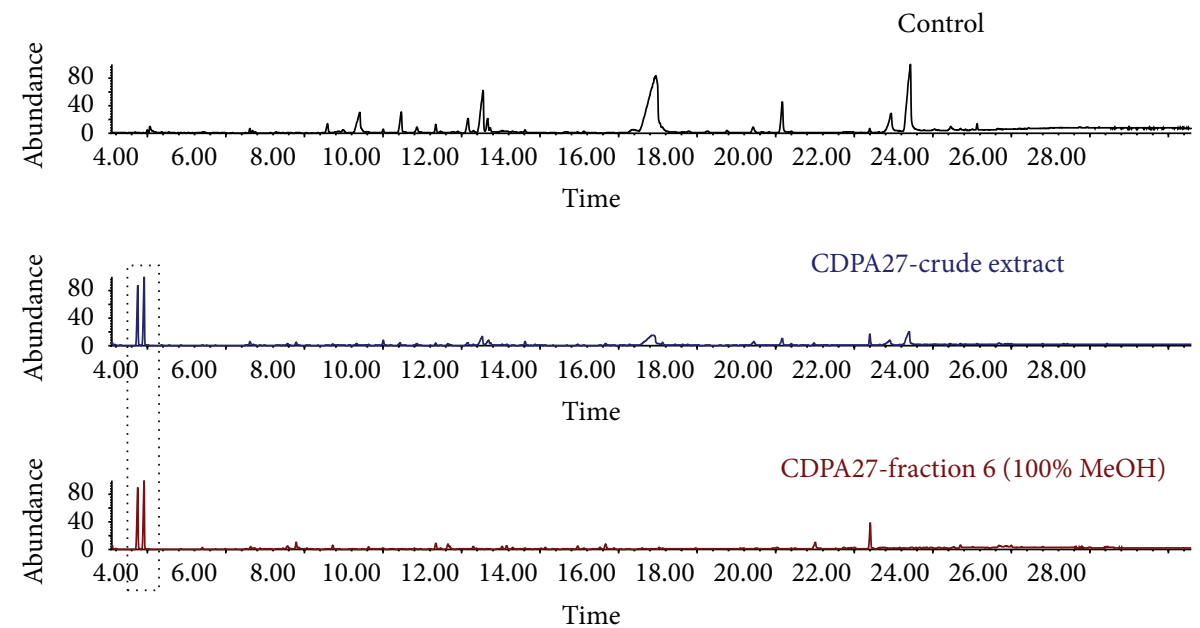

FIGURE 5: Chromatographic analyses of the control, CDPA27 (crude extract), and fraction $6(100 \% \mathrm{MeOH})$.

of this bacterial strain. Chartreusin is described in the utilized database, thereby eliminating the possibility that the antiviral activity described in the present study can be attributed to this compound (Figure 4, Table 2).

In conclusion, the data obtained in the present study were used to identify a bacterial species isolated from termites, that is, a promising producer of secondary metabolites with antiviral activities against BVDV, which serves as a surrogate model of HCV. From this study, it can be concluded that Actinomycetes collected and isolated from termite mounds can be used as sources of pharmacologically active compounds that may be used for the synthesis of new drugs to treat patients with hepatitis C. However, further studies are needed to identify the active compound(s) in the extracts that were evaluated in this study.

\section{Conflict of Interests}

The authors have no conflict of interests to declare.

\section{Acknowledgment}

This work was financially supported by FAPESP (Fundação de Amparo à Pesquisa do Estado de São Paulo) under Grant Projeto Cupim and 2011/50919-5 and CNPq (Grant 311779/2014-0).

\section{References}

[1] K. Nishine, H. Aoki, Y. Sakoda, and A. Fukusho, "Field distribution of END phenomenon-negative Bovine Viral Diarrhea virus," The Journal of Veterinary Medical Science, vol. 76, no. 12, pp. 1635-1639, 2014.

[2] P. Mahmoodi, M. R. Seyfi Abad Shapouri, M. Ghorbanpour et al., "Epitope mapping of bovine viral diarrhea virus nonstructural protein 3," Veterinary Immunology and Immunopathology, vol. 161, no. 3-4, pp. 232-239, 2014.

[3] J. C. S. Bastos, L. K. Kohn, F. Fantinatti-Garboggini et al., "Antiviral activity of Bacillus sp. isolated from the marine sponge petromica citrina against bovine viral diarrhea virus, a surrogate model of the hepatitis C virus," Viruses, vol. 5, no. 5, pp. 1219-1230, 2013.

[4] T. F. Kubiça, S. H. Alves, R. Weiblen, and L. T. Lovato, "In vitro inhibition of the bovine viral diarrhoea virus by the essential oil of Ocimum basilicum (basil) and monoterpenes," Brazilian Journal of Microbiology, vol. 45, no. 1, pp. 209-214, 2014.

[5] H.-W. Xu, L.-J. Zhao, H.-F. Liu et al., "Synthesis and anti-BVDV activity of novel $\delta$-sultones in vitro: implications for $\mathrm{HCV}$ therapies," Bioorganic and Medicinal Chemistry Letters, vol. 24, no. 10, pp. 2388-2391, 2014.

[6] C. Han, Y. Guo, D. Wang et al., "Novel pyrazole fused heterocyclic ligands: synthesis, characterization, DNA binding/cleavage activity and anti-BVDV activity," Chinese Chemical Letters, vol. 26, no. 5, pp. 534-538, 2015.

[7] D. Rupp and R. Bartenschlager, "Targets for antiviral therapy of hepatitis C," Seminars in Liver Disease, vol. 34, no. 1, pp. 9-21, 2014.

[8] N. A. Gogela, M. V. Lin, J. L. Wisocky, and R. T. Chung, "Enhancing our understanding of current therapies for hepatitis C virus (HCV)," Current HIV/AIDS Reports, vol. 12, no. 1, pp. 68-78, 2015.

[9] V. P. Bagla, L. J. McGaw, and J. N. Eloff, "The antiviral activity of six South African plants traditionally used against infections in ethnoveterinary medicine," Veterinary Microbiology, vol. 155, no. 2-4, pp. 198-206, 2012.

[10] D. A. Dias, S. Urban, and U. Roessner, "A historical overview of natural products in drug discovery," Metabolites, vol. 2, no. 4, pp. 303-336, 2012.

[11] A. Solavan, R. Paulmurugan, V. Wilsanand, and A. J. A. Sing, "Traditional therapeutic uses of animals among trial population of Tamil Nadu," Indian Journal of Traditional Knowledge, vol. 3, no. 2, pp. 198-205, 2004.

[12] E. M. C. Neto, J. Ramos-Elorduy, and J. M. Pino, "Los insectos medicinales de Brasil: primeiros resultados," Boletín Sociedad Entomológica Aragonesa, vol. 1, no. 38, pp. 395-414, 2006.

[13] A. Solavan, R. Paulmurugan, and V. Wilsanand, "Antibacterial activity of subterranean termites used in south Indian folk medicine," Indian Journal of Traditional Knowledge, vol. 6, no. 4, pp. 559-562, 2007. 
[14] K. Khucharoenphaisan, N. Sripairoj, and K. Sinma, "Isolation and identification of actinomycetes from termite's gut against human pathogen," Asian Journal of Animal and Veterinary Advances, vol. 7, no. 1, pp. 68-73, 2012.

[15] D. Van Soolingen, P. E. W. De Haas, P. W. M. Hermans, P. M. A. Groenen, and J. D. A. Van Embden, "Comparison of various repetitive DNA elements as genetic Markers for strain differentiation and epidemiology of Mycobacterium tuberculosis," Journal of Clinical Microbiology, vol. 31, no. 8, pp. 1987-1995, 1993.

[16] D. J. Lane, "16S/23S rRNA sequencing," in Nucleic Acid Techniques in Bacterial Systematics, M. Goodfellow and E. Stackebrandt, Eds., pp. 115-147, John Wiley \& Sons, Chichester, UK, 1991.

[17] B. Ewing, L. Hillier, M. C. Wendl, and P. Green, "Basecalling of automated sequencer traces using Phred. I. Accuracy assessment," Genome Research, vol. 8, no. 3, pp. 175-185, 1998.

[18] D. Gordon, C. Abajian, and P. Green, "Consed: a graphical tool for sequence finishing," Genome Research, vol. 8, no. 3, pp. 195202, 1998.

[19] J. D. Thompson, T. J. Gibson, F. Plewniak, F. Jeanmougin, and D. G. Higgins, "The CLUSTAL X windows interface: flexible strategies for multiple sequence alignment aided by quality analysis tools," Nucleic Acids Research, vol. 25, no. 24, pp. 48764882, 1997.

[20] K. Tamura, D. Peterson, N. Peterson, G. Stecher, M. Nei, and S. Kumar, "MEGA5: molecular evolutionary genetics analysis using maximum likelihood, evolutionary distance, and maximum parsimony methods," Molecular Biology and Evolution, vol. 28, no. 10, pp. 2731-2739, 2011.

[21] M. Kimura, "A simple method for estimating evolutionary rates of base substitutions through comparative studies of nucleotide sequences," Journal of Molecular Evolution, vol. 16, no. 2, pp. 111120, 1980.

[22] N. Saitou and M. Nei, "The neighbor-joining method: a new method for reconstructing phylogenetic trees," Molecular Biology and Evolution, vol. 4, no. 4, pp. 406-425, 1987.

[23] J. Felsenstein, "Confidence limits on phylogenies: an approach using the bootstrap," Evolution, vol. 39, no. 4, p. 783, 1985.

[24] T. Mosmann, "Rapid colorimetric assay for cellular growth and survival: application to proliferation and cytotoxicity assays," Journal of Immunological Methods, vol. 65, no. 1-2, pp. 55-63, 1983.

[25] D. A. Scudiero, R. H. Shoemaker, K. D. Paull et al., "Evaluation of a soluble tetrazolium/formazan assay for cell growth and drug sensitivity in culture using human and other tumor cell lines," Cancer Research, vol. 48, no. 17, pp. 4827-4833, 1988.

[26] L. J. Reed and H. A. Münch, "A simple method of estimating fifty percent endpoints," American Journal of Epidemiology, vol. 27, no. 3, pp. 493-497, 1938.

[27] H. Takeuchi, M. Baba, and S. Shigeta, "An application of tetrazolium (MTT) colorimetric assay for the screening of anti-herpes simplex virus compounds," Journal of Virological Methods, vol. 33, no. 1-2, pp. 61-71, 1991.

[28] I. Koseki, I. C. Simoni, I. T. Nakamura, A. B. Noronha, and S. S. Costa, "Antiviral activity of plant extracts against aphthovirus, pseudorabies virus and pestivirus in cell cultures," Microbios Letters, vol. 44, no. 173, pp. 19-30, 1990.

[29] L. M. Finkielsztein, G. Y. Moltrasio, M. E. Caputto, E. F. Castro, L. V. Cavallaro, and A. G. Moglioni, "What is known about the antiviral agents active against bovine viral diarrhea virus
(BVDV)?" Current Medicinal Chemistry, vol. 17, no. 26, pp. 2933-2955, 2010.

[30] C. Sarrazin and S. Zeuzem, "Resistance to direct antiviral agents in patients with hepatitis C virus infection," Gastroenterology, vol. 138, no. 2, pp. 447-462, 2010.

[31] S. I. Venâncio, A. A. Bersusa, P. N. Martins, G. Figueiredo, A. Awakamatsu, and V. A. Alves, "Avaliação do processo de dispensação de medicamentos aos portadores de hepatite $\mathrm{C}$ crônica em farmácias de componentes especializados da Secretaria de Estado da Saúde de São Paulo, em 2010," Epidemiologia e Serviços de Saúde, vol. 23, no. 4, pp. 701-710, 2014.

[32] J. Tong, H. Trapido-Rosenthal, J. Wang, Y. Wang, Q. X. Li, and Y. Lu, "Antiviral activities and putative identification of compounds in microbial extracts from the Hawaiian coastal waters," Marine Drugs, vol. 10, no. 3, pp. 521-538, 2012.

[33] L. K. Kohn, C. L. Queiroga, M. C. Martini et al., "In vitro antiviral activity of Brazilian plants (Maytenus ilicifolia and Aniba rosaeodora) against bovine herpesvirus type 5 and avian metapneumovirus," Pharmaceutical Biology, vol. 50, no. 10, pp. 1269-1275, 2012.

[34] Y.-L. Zhang, S. Li, D.-H. Jiang, L.-C. Kong, P.-H. Zhang, and J.-D. Xu, "Antifungal activities of metabolites produced by a termite-associated Streptomyces canus BYB02," Journal of Agricultural and Food Chemistry, vol. 61, no. 7, pp. 1521-1524, 2013.

[35] T. Matsui, J. Tanaka, T. Namihira, and N. Shinzato, "Antibiotics production by an actinomycete isolated from the termite gut," Journal of Basic Microbiology, vol. 52, no. 6, pp. 731-735, 2012.

[36] D. E. Bignell, H. Oskarsson, and J. M. Anderson, "Association of actinomycete-like Bacteria with soil-feeding termites (Termitidae, Termitinae)," Applied and Environmental Microbiology, vol. 37, no. 2, pp. 339-342, 1979.

[37] M. B. Pasti, A. L. Pometto III, M. P. Nuti, and D. L. Crawford, "Lignin-solubilizing ability of actinomycetes isolated from termite (termitidae) gut," Applied and Environmental Microbiology, vol. 56, no. 7, pp. 2213-2218, 1990.

[38] H. Chen, C. Yang, T. Ke et al., "Antimicrobial activity of secondary metabolites from Streptomyces sp. K15, an endophyte in Houttuynia cordata Thunb," Natural Product Research, vol. 29, no. 23, pp. 2223-2225, 2015.

[39] M. Yassien, H. Abdallah, A. El-Halawany, and A. JimanFatani, "Anti-tuberculous activity of Treponemycin produced by a Streptomyces strain MS-6-6 isolated from Saudi Arabia," Molecules, vol. 20, no. 2, pp. 2576-2590, 2015.

[40] A. Raveh, P. C. Delekta, C. J. Dobry et al., "Discovery of potent broad spectrum antivirals derived from marine actinobacteria," PLoS ONE, vol. 8, no. 12, Article ID e82318, 2013.

[41] B. E. Leach, K. M. Calhoun, L. E. Johnson, C. M. Teeters, and W. G. Jackson, "Chartreusin, a new antibiotic produced by Streptomyces chartreusis, a new species," Journal of the American Chemical Society, vol. 75, no. 16, pp. 4011-4012, 1953.

[42] T. Miyakawa, O. Anzai, and N. Shimizu, "Studies on antiviral antibiotics from streptomyces-VIII. Various antibiotics as inhibitors of influenza virus in tissue culture," Japanese Journal of Microbiology, vol. 2, no. 1, pp. 53-62, 1958.

[43] K. N. Venugopala, V. Rashmi, and B. Odhav, "Review on natural coumarin lead compounds for their pharmacological activity," BioMed Research International, vol. 2013, Article ID 963248, 14 pages, 2013.

[44] Y. Aoyama, T. Katayama, M. Yamamoto, H. Tanaka, and K. Kon, "A new antitumor antibiotic product, demethylchartreusin. 
Isolation and biological activities," Journal of Antibiotics, vol. 45, no. 6, pp. 875-878, 1992.

[45] Y.-W. Chin, M. J. Balunas, H. B. Chai, and A. D. Kinghorn, "Drug discovery from natural sources," The AAPS Journal, vol. 8, no. 2, pp. E239-E253, 2006. 


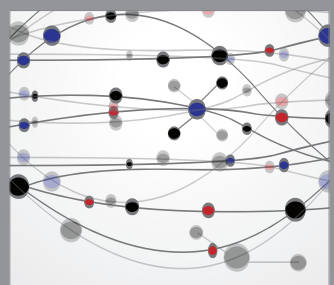

The Scientific World Journal
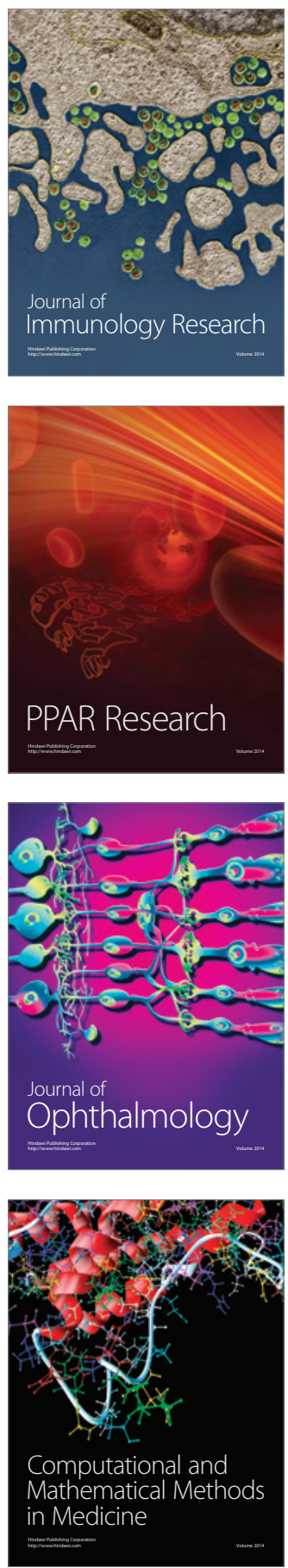

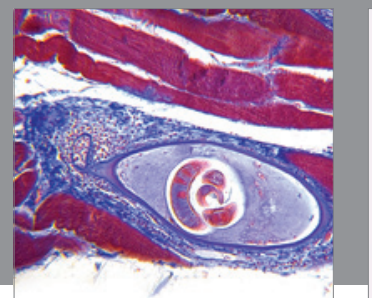

Gastroenterology

Research and Practice
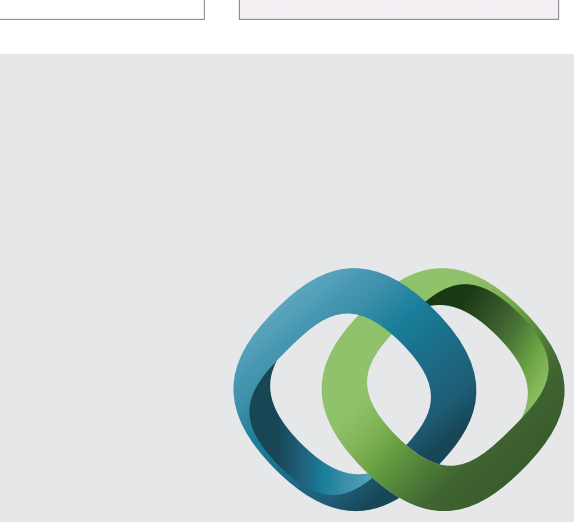

\section{Hindawi}

Submit your manuscripts at

http://www.hindawi.com
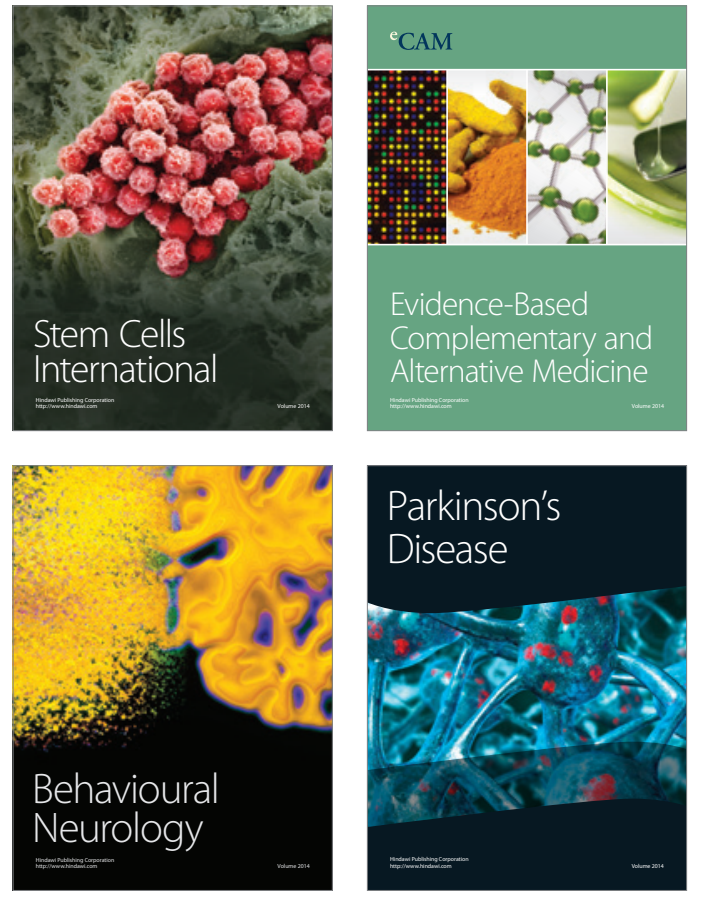
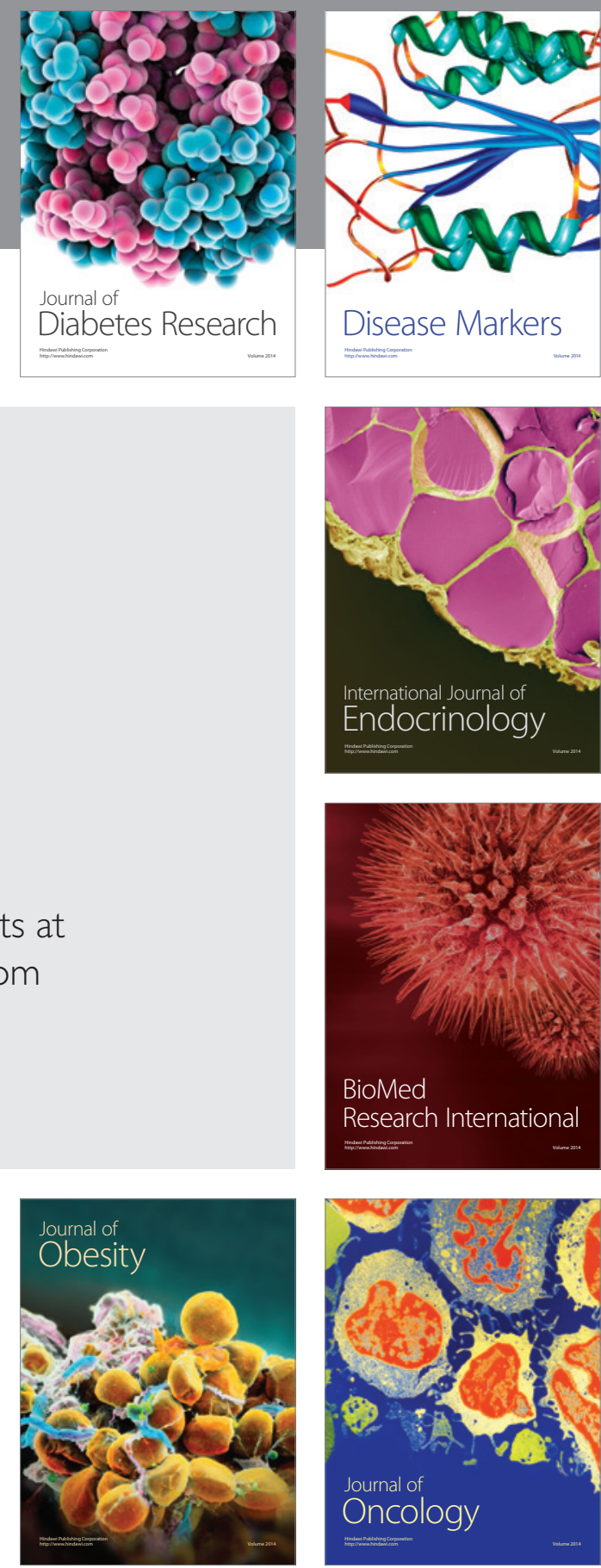

Disease Markers
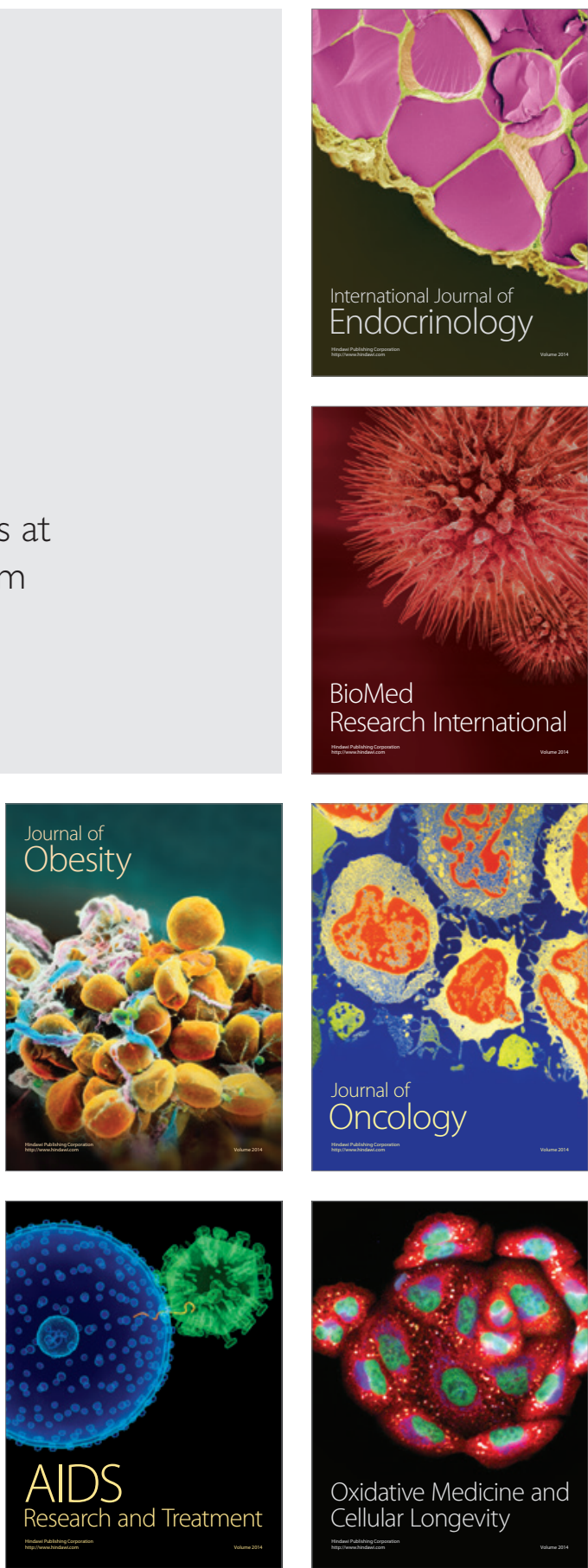